\title{
Bacteroides bundle of joy: sepsis from a degenerating/necrotic fibroid
}

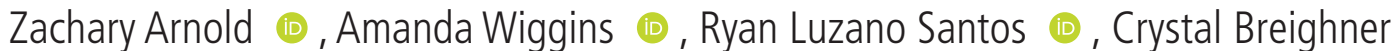

Internal Medicine, Tripler Army Medical Center, Honolulu, Hawaii, USA

\section{Correspondence to} Dr Amanda Wiggins; amanda.keith8@gmail.com

Accepted 30 July 2020

\section{DESCRIPTION}

A woman of childbearing age with a history of uterine leiomyoma presented to the emergency department with pelvic pain. Ten months prior to presentation, she was evaluated by an obstetric and gynecologic physician for menometrorrhagia. At that time, she was found to have a $4.9 \times 5.7 \times 6.9$ $\mathrm{cm}$ intramural leiomyoma on ultrasound. Endometrial biopsy confirmed the diagnosis of leiomyoma. A hormonal intrauterine device was placed for treatment of menometrorrhagia 8 months prior to presentation. Her menometrorrhagia improved but her pelvic pain gradually worsened over the subsequent months. On the day of presentation, her pelvic pain escalated with associated chills and rigours, prompting her visit to the emergency room.

In the emergency room, she was tachycardic, tachypnic and febrile to $40.5^{\circ} \mathrm{C}$. Significant laboratory findings included an elevated procalcitonin at $4.63 \mathrm{ng} / \mathrm{mL}$, thrombocytopenia and lactic acidosis. An abdominal and pelvic CT scan showed enlargement of the known leiomyoma to $8.9 \times 10.2 \times 10.2$ $\mathrm{cm}$. She was admitted to the hospital and started on broad spectrum antibiotics for sepsis secondary to a presumed genitourinary source. A thorough history, physical examination, further laboratory evaluation and review of imaging revealed no evidence for acute cystitis, pyelonephritis, appendicitis, cholangitis, pancreatitis, pneumonia, cellulitis, meningitis or encephalitis. On hospital day 2, blood cultures were positive; Gram stain showed Gram-negative rods. Culture growth speciated to Bacteroides fragilis. An MRI of the pelvis with contrast showed a large heterogeneously T2 hyperintense mass within the uterus (figure 1). A central

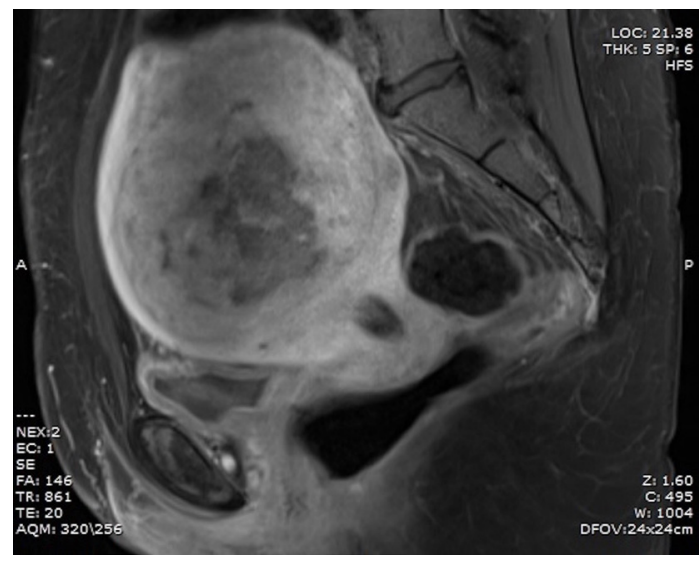

Figure 1 Pelvic MRI with contrast sagittal T1 with an $8.9 \times 10.2 \times 10.2 \mathrm{~cm}$ mass, evidence of central haemorrhage or necrotic tissue.

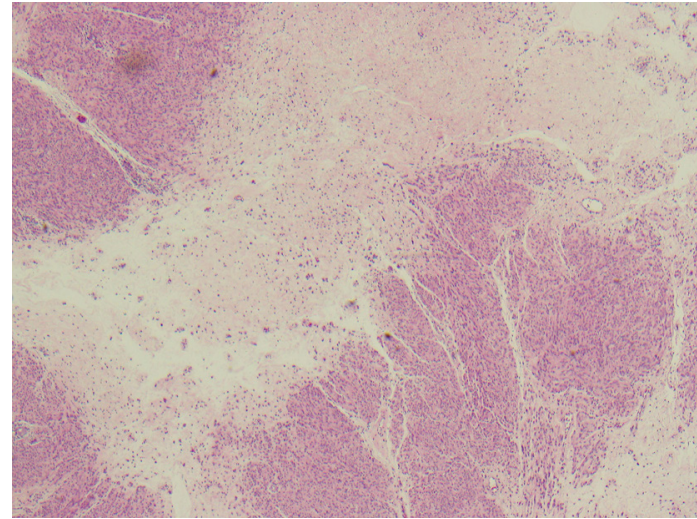

Figure 2 Histopathologic evidence of leiomyoma with abscess and extensive necrosis.

T1 hyperintense non-enhancing component was noted within the mass. These findings most likely represented a degenerating submucosal fibroid with central haemorrhage or necrotic products. An endometrial biopsy showed proliferative pattern endometrium with abundant suppuration inflammation without hyperplasia or malignancy. She was ultimately diagnosis with sepsis secondary to B. fragilis bacteremia from a pyomyoma. During her hospitalisation, she was treated with intravenous ampicillin/sulbactam and metronidazole, and then transitioned to amoxicillin/clavulanic acid and oral metronidazole for a total of 14 days. Following completion of her antibiotics, she had an open myomectomy. Surgery proceeded without complication and histopathology confirmed myometrial tissue with extensive necrosis and abscess formation (figure 2).

Pyomyoma is known to be a rare condition where a fibroid has outgrown its blood supply, undergoes necrosis and becomes infected with pus formation. However, typically, these case reports occur after spontaneous abortion or pregnancy with associated complication rate with pregnancy of $2 \%{ }^{12}$ Those not associated with pregnancy have generally been

\section{Learning points}

Pyomyoma, or suppurative leiomyoma of the uterus, is infection of a leiomyoma.

- The triad of pain, sepsis without a clear source and known history of leiomyoma should raise suspicion for pyomyoma.

- Radiological characteristics of pyomyoma include gas formation and fibrous capsules. 
in postmenopausal women. ${ }^{2}$ This diagnosis should be considered when faced with the triad of pain, sepsis without a clear cause and known diagnosis of leiomyoma due to the high mortality rate of $20 \%-30 \% .^{2}{ }^{3}$ MRI can be useful in the diagnosis of pyomyoma by detecting fibrous capsules. ${ }^{45}$

Contributors ZA, AW and CB contributed equally to the concept, drafting and revising of the manuscript. RLS contributed to the image development. All authors gave final approval of the manuscript prior to submission.

Funding The authors have not declared a specific grant for this research from any funding agency in the public, commercial or not-for-profit sectors.

Competing interests None declared.

Patient consent for publication Obtained.

Provenance and peer review Not commissioned; externally peer reviewed.

\section{ORCID iDs}

Zachary Arnold http://orcid.org/0000-0002-9108-2552

Amanda Wiggins http://orcid.org/0000-0001-5561-9546

Ryan Luzano Santos http://orcid.org/0000-0002-0403-3809

\section{REFERENCES}

1 Greenspoon JS, Ault M, James BA, et al. Pyomyoma associated with polymicrobial bacteremia and fatal septic shock: case report and review of the literature. Obstet Gynecol Surv 1990;45:563-9.

2 Mason TC, Adair J, Lee YC. Postpartum pyomyoma. J Natl Med Assoc 2005;97:826-8.

3 Ono $\mathrm{H}$, Kanematsu $\mathrm{M}$, Kato $\mathrm{H}$, et al. Mr imaging findings of uterine pyomyoma: radiologic-pathologic correlation. Abdom Imaging 2014;39:797-801.

4 Read S, Mullins J. Spontaneous ruptured Pyomyoma in a nulligravid female: a case report and review of the literature. Case Rep Obstet Gynecol 2018;2018:1-6.

5 Sirha R, Miskin A, Abdelmagied A. Postnatal pyomyoma: a diagnostic dilemma. BMJ Case Rep 2013;2013:2013.

Copyright 2020 BMJ Publishing Group. All rights reserved. For permission to reuse any of this content visit

https://www.bmj.com/company/products-services/rights-and-licensing/permissions/

BMJ Case Report Fellows may re-use this article for personal use and teaching without any further permission.

Become a Fellow of BMJ Case Reports today and you can:

- Submit as many cases as you like

- Enjoy fast sympathetic peer review and rapid publication of accepted articles

- Access all the published articles

Re-use any of the published material for personal use and teaching without further permission

Customer Service

If you have any further queries about your subscription, please contact our customer services team on +44 (0) 2071111105 or via email at support@bmj.com.

Visit casereports.bmj.com for more articles like this and to become a Fellow 